\title{
Character Schools in Supporting Character Education in Students
}

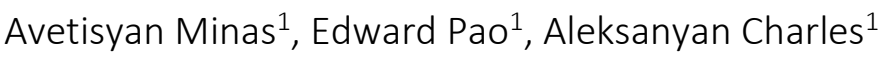 \\ Special Education Department, Ain Syams University, Egypt \\ *Corresponding Author: Avetisyan Minas
}

Received: November 28, 2020

Revised: December 12, 2020

Accepted: December 18, 2020

\begin{abstract}
Character education is stated as value education, character education, moral education, character education which aims to develop the ability of all school members to make good and bad decisions, exemplify, maintain what is good \& realize that good in everyday life wholeheartedly.Character education is placed as the foundation for realizing the vision of national development, namely realizing a society with noble, moral, ethical, cultured, and civilized characters based on the philosophy. This is at the same time an effort to support the realization of the ideals as mandated in the Pancasila and the Preamble to the 1945 Constitution. In addition, the various problems faced by our nation today have increasingly encouraged the enthusiasm and efforts of the government to prioritize character education as the basis for educational development.
\end{abstract}

Keywords: Character Education, Moral Education, Educational Development

\section{Introduction}

Efforts to build character in accordance with the culture of this nation are certainly not only carried out in schools through a series of teaching and learning activities outside of school, but also through habituation in life, such as: religious, honest, disciplined, tolerant, hard work, peace, responsibility, and so on. This habit not only teaches knowledge about right and wrong things, but is also able to feel the good and bad values, and is willing to do it from the smallest scope such as family to a wider scope in society. These values need to be nurtured by students who will eventually become a reflection of the life of the Indonesian nation. Therefore, schools have a big role in developing character education because of the role of schools as centers of culture through the school culture development approach.

Schools are seen as one of the preventive alternatives because schools build a new, better nation generation. As a preventive alternative, schools are expected to develop the quality of the nation's young generation in various aspects that can minimize and reduce the causes of various cultural problems and national character (Beller et al., 2007; Berkowitz et al., 2004; Dekawati, 2020; Babiak, 2020). It is recognized that the results of education carried out in schools will have an impact in the not immediate future, but have a strong endurance and impact on society. School is one part of the development of national character and culture education. The strategies for becoming a school with character can be summarized as staff involvement, student involvement, and parental involvement. All of these are the objectives of the group whose participation is crucial for the success of a school's character education initiative. This chapter focuses on the places where character education needs to start, with school staff. To make the school more character! 


\section{Creating Milestones}

Creating milestones can start by researching the school's mission statement (usually longer, more complex, and harder to remember than any milestone statement). What ethical and intellectual values does this mission express? What importance is missing or should be made more explicit in a milestone? A school committee can then write down four or five "we," as it is in Slaven's way of presenting a statement or school milestone and listen to this draft for all staff, students, and people to get their input (for a copy of Educating for Character in the Denver Public Schols, with suggested steps for setting school milestones.

\section{Character Based Motto}

Does the school statement or school creed live in the hearts and minds of staff and students? One way to help is to choose a school motto - ideally, a statement of belief in a milestone that captures the essence of the milestone and makes the motto an important part of the school culture. Here's an example of the school's motto: "whatever hurts my brother hurts me too".

\section{Seeking Principal's Support to Make Character a Priority}

At the third point, this is to seek the support of the principal in shaping character to be a priority where the principal must be able and able to make character education the main priority in school, the principal must be aware of the importance of character education as a way of forming people who have good attitudes, responsibilities, disciplined, and honest. After the principal has made character education a top priority, the principal and his staff must also provide mutual support for both staff and teaching staff.

\section{Forming a Leadership Group.}

Building a school of character requires a leadership team to plan and support implementation. At this point it is hoped that the school will form a character team where this team or this group forms a structure in relation to character education and in the group it will also be divided into several members who have different duties and responsibilities in terms of character building. I hope that students can see and imitate that forming a group of characters will make us better students.

\section{Developing a Knowledge Base}

The leadership team needs character education insight. Currently there are dozens of character education websites that can assist teachers in implementing character education in schools, one of which is: www.character.org teachers can access the character site as reading material and references in building character education, after the teacher accesses the site the teacher also can inform or teach about the character education site to students so that teachers and students can learn together in the character education. Teachers can also make visits to schools that have implemented character education, and ask what programs have been implemented and what programs have been successful.

\section{Introducing the Concept of Character Education to All Staff}

Character education should actually involve all elements and components of the school including the principal component and the teacher staff component etc. In order for the formation of biased character to be better, at this point character building discusses staff 
involvement in the formation of character education, this introductory session must raise four fundamental questions: (1) what is the goal of character education? (2) what do I need in my job? (3) what happens if we do it throughout the school? (4) what are the advantages if we implement this program ?. Let's see how we can approach each of these questions.

\section{Consider "What Kind of Personality Type Do We Want From Students?"}

There are three goals for character education: a personality with good character, a school with character, and a community with character. This raises an important question, what is meant by "good character" a teacher considers what character to achieve in students, whether to create a character with a good character, a school with character and or a community with character. Principals and staff must ignore 10 essential policies, namely: (wisdom, justice, fortitude, self-justice, love, positive attitude, hard work, integrity, gratitude and humility) in shaping a character with a personality (Wasserman \& Frenkel, 2011; Zweiniger-Bargielowska, 2006).

\section{Consider "Whether the Character Education will Work Throughout the School}

When staff begin to feel comfortable with the meaning of character education in their individual work, they are ready to consider the meaning of character education for the whole school. A quick way to convey the meaning of character education for schools is to look at reading case studies and discuss character education success stories from across the country. When a school staff sees how similar schools face the same problems and has improved student learning and behavior and staff morale through character education, they naturally think.

Here's how I recommend that character education be implemented in all schools: gather staff and form them in three groups after three groups are formed, then we provide reading material about the success of character education in primary schools and up to college, then the staff is asked to give which signs have been implemented in the school and which will be planned in the future, after that the staff explained to each group and then the staff was asked to develop strategies in implementing the character education. If the school staff then commit to making their school a character school, then the method above can be taken as the starting point for a character education plan (Lee, 2009; Lickona, 2004; Motti et al., 2004).

\section{Analyzing the Moral and Intellectual School Culture}

The next step is to look more closely at the strengths and areas for improvement in the moral and intellectual culture of the school. This step is a step that is really needed in creating a character school. If this step is not taken, then a school will have a very big problem in implementing character education. At this point we are expected to analyze school culture and school intellectuals whether they reflect character habits and also analyze whether intellectual habits reflect character habits. If the moral and intellectual culture of the school in question is not a matter of vibrant and continuous reflection, then the character of a school and all its efforts in character education will be bad.

\section{Choosing Dau Priority to Improve School Culture}

Reflection must be accompanied by action. The first step in designing an action plan to strengthen the school culture is to focus on only one or two of the concerns outlined in the analysis above. In a school, one or two priorities must be chosen in improving the school 
culture when the school already has a top priority, so the school and some of the staff in it will do their best to achieve the desired focus, for example, at the beginning of each new school year the principal focuses improving character education in the school, so at the beginning of the new school year the principal and his staff will work on improving character education for the next one year.

\section{Ask "Should We Commit to Being a Character School"}

The next step is to decide, should we commit to being a school with character? If so, what action should we take toward this goal? If all the preceding cases have been done well, there is a strong possibility that the majority of the staff will say yes, and it makes sense for us to commit to being a school of character. At this point, the staff should think that character education is basically about helping children become good students and societies by being the best schools possible in any case.

\section{Planning a Quality Character Education Program}

The next task is to plan the substance of the character education program. The challenge is to design a program that has most, if not all, of the components that make up quality character education. Here are twenty components - a kind of character education audit that recurs in character education success stories. Five of these in the past I will list: (1) Leadership / administrative support, including, ideally, education coordinators. (2) Strong staff involvement. (3) Strong student involvement. (3) Strong parental involvement. (4) Milestones (creeds / statements) of schools and mottos that emphasize character.

\section{Choosing an Organizational Strategy to Encourage Goodness}

School staff must also discuss and decide how to organize its character education program. Here are 5 out of ten solutions, many of which can be combined: (1) One good a month. (2) One good one week, related to the monthly theme. (3) The three or four year cycle of goodness (six times a year, six more in the following year, and so on), thereby avoiding repeating the same kindness year after year (like an annual program). (4) Annual themes (such as "peaceful years", disciplinary years "years of courage") are often linked or combined with a quarterly focus (eg encouraging peace in our class, encouraging discipline in our class, etc.).

By using an organizational strategy in goodness and combining or combining with these five points, good character will be formed in one school, and the emphasis is on the principal, staff and teachers as the driving force of these steps or methods.

\section{Making Assessments as Part of Planning}

There are at least three reasons that are important to assess a character education initiative (DiPaola \& Walther-Thomas, 2003; Duke \& Salmonowicz, 2010; Fink \& Geller, 2016). (1) what is measured, matters; staff motivation and accountability for implementing education efforts will be much better when it comes to planning to assess outcomes; (2) the assessment will tell you to what extent your previous character education program made a difference; and (3) assessment data can then be used to guide decision making about how to improve the effectiveness of the program. Here are some questions that can evaluate how the application of character education in your school is: (1) To what extent do staff implement character education, as desired (2) To what extent do students understand the goodness of the objectives taught in their class (3) To what extent the level of development in practicing 
kindness (4) To what extent do students' behavior experience improvement or improvement in certain parts of the school environment or in school life. Here are some ways to evaluate the success of character education that is applied in schools.

\section{Builds Strong Adult Communication}

In the long run, the quality of a school's character education efforts will be a function of the quality of the adult community. To what degree do staff know, respect and support one another? Strengthening a staff's sense or community understanding can be as simple as making sure people feel appreciated or valued. This point explains the importance of building strong communication between schools with strong adults or with parents so that character education can run well and have strong support or strong communication between teachers and parents of students, the methods offered are very good. Involving students' parents in attending meetings and exchanging opinions and giving notes to the parents of students so that they can help teachers and schools in overcoming various kinds of problems in character education.

\section{Ask "Should We Commit to Being a Character School"}

The next step is to decide, should we commit to being a school with character? If so, what action should we take toward this goal? If all the preceding cases have been done well, there is a strong possibility that the majority of the staff will say yes, and it makes sense for us to commit to being a school of character. At this point, the staff should think that character education is basically about helping children become good students and societies by being the best schools possible in any case.

\section{Planning a Quality Character Education Program}

The next task is to plan the substance of the character education program. The challenge is to design a program that has most, if not all, of the components that make up quality character education. Here are twenty components - a kind of character education audit that recurs in character education success stories. Five of these in the past I will list: (1) Leadership / administrative support, including, ideally, education coordinators. (2) Strong staff involvement. (3) Strong student involvement. (3) Strong parental involvement. (4) Milestones (creeds / statements) of schools and mottos that emphasize character.

\section{Choosing an Organizational Strategy to Encourage Goodness}

School staff must also discuss and decide how to organize its character education program. Here are 5 out of ten solutions, many of which can be combined: (1) One good a month. (2) One good one week, related to the monthly theme. (3) The three or four year cycle of goodness (six times a year, six more in the following year, and so on), thereby avoiding repeating the same kindness year after year (like an annual program). (4) Annual themes (such as "peaceful years", disciplinary years "years of courage") are often linked or combined with a quarterly focus (eg encouraging peace in our class, encouraging discipline in our class, etc.).

By using an organizational strategy in goodness and combining or combining with these five points, good character will be formed in one school, and the emphasis is on the principal, staff and teachers as the driving force of these steps or methods (Hasib et al., 2017).

\section{Making Assessments as Part of Planning}


There are at least three reasons that are important to assess a character education initiative: (1) what is measured, matters; staff motivation and accountability for implementing education efforts will be much better when it comes to planning to assess outcomes; (2) the assessment will tell you to what extent your previous character education program made a difference; and (3) assessment data can then be used to guide decision making about how to improve the effectiveness of the program. Here are some questions that can evaluate how the application of character education in your school is: (1) To what extent do staff implement character education, as desired (2) To what extent do students understand the goodness of the objectives taught in their class (3) To what extent the level of development in practicing kindness (4) To what extent do students' behavior experience improvement or improvement in certain parts of the school environment or in school life. Here are some ways to evaluate the success of character education that is applied in schools.

\section{Builds Strong Adult Communication.}

In the long run, the quality of a school's character education efforts will be a function of the quality of the adult community. To what degree do staff know, respect and support one another? Strengthening a staff's sense or community understanding can be as simple as making sure people feel appreciated or valued. This point explains the importance of building strong communication between schools with strong adults or with parents so that character education can run well and have strong support or strong communication between teachers and parents of students, the methods offered are very good. Namely by involving students' parents in attending meetings and exchanging opinions and giving notes to the parents of students so that they can help teachers and schools in overcoming various kinds of problems in character education (Pane \& Patriana, 2016; Robbins \& Alvy, 2003; Taras et al., 2011).

\section{Conclusion}

Education is defined as a system of inculcating character values to school members which includes components of knowledge, awareness or willingness, and actions to carry out these values, both towards God Almighty, self, neighbor, environment, and nationality so that we become a human being.

In character education in schools, all components (stakeholders) must be involved, including the components of the education itself, namely curriculum content, learning and assessment processes, quality of relationships, handling or management of subjects, school management, implementing activities or co-curricular empowerment activities of infrastructure, financing, and work ethic of all residents and the school environment, in order to create a good and character education system.

\section{References}

Babiak, O. (2020). Communication Peculiarities of Adolescents with Mental Retardation in Student Group. Journal La Edusci, 1(3), 17-22.

Beller, M., \& Leerssen, J. T. (Eds.). (2007). Imagology: the cultural construction and literary representation of national characters: a critical survei, (Vol. 13). Rodopi.

Berkowitz, M. W., \& Bier, M. C. (2004). based character education. The Annals of the American Academy of Political and Social Science, 591(1), 72-85. 
Dekawati, I. (2020). THE PRINCIPAL'S LEADERSHIP AS THE EFFORT TO BUILD STUDENTS'CHARACTER. International Journal of Educational Management and Innovation, 1(2), 109-119.

DiPaola, M. F., \& Walther-Thomas, C. (2003). Principals and Special Education: The Critical Role of School Leaders.

Duke, D., \& Salmonowicz, M. (2010). Key decisions of a first-year 'turnaround'principal. Educational Management Administration \& Leadership, 38(1), 33-58.

Fink, K., \& Geller, K. (2016). Integrating Common Core and character education: Why it is essential and how it can be done. Journal of Character Education, 12(1), 55.

Hasib, M., Nahruddin, Z., Tahir, M. M., Handam, M., Akbar, M. F., \& Nurdiansyah, W. (2017). Local Wisdom and Character Education in Youth Organizations--A Case Study of South Sulawesi Province, Indonesia. In International Conference on Administrative Science (ICAS 2017). Atlantis Press.

Lee, C. M. (2009). The planning, implementation and evaluation of a character-based school culture project in Taiwan. Journal of Moral Education, 38(2), 165-184.

Lickona, T. (2004). Character matters: How to help our children develop good judgment, integrity, and other essential virtues. Simon and Schuster.

Motti, R., Regev, M., \& Seroussi, E. (2004). Popular music and national culture in Israel. Univ of California Press.

Pane, M. M., \& Patriana, R. (2016). The significance of environmental contents in character education for quality of life. Procedia-Social and Behavioral Sciences, 222, 244-252.

Robbins, P., \& Alvy, H. B. (2003). The principal's companion: Strategies and hints to make the job easier. Corwin Press.

Taras, V., Steel, P., \& Kirkman, B. L. (2011). Three decades of research on national culture in the workplace: Do the differences still make a difference. Organizational Dynamics, 40(3), 189-198.

Wasserman, V., \& Frenkel, M. (2011). Organizational aesthetics: Caught between identity regulation and culture jamming. Organization Science, 22(2), 503-521.

Zweiniger-Bargielowska, I. (2006). Building a British superman: physical culture in interwar Britain. Journal of Contemporary History, 41(4), 595-610. 